\title{
Muscarinic receptors in gastric mucosa are increased in peptic ulcer disease
}

\author{
A Pfeiffer, W Krömer, J Friemann, M Ruge, M Herawi, M Schätzl, U Schwegler, B May, \\ H Schatz
}

\begin{abstract}
Muscarinic receptors stimulate the secretion of acid pepsinogen and mucous in gastric mucosa. Whether muscarinic receptors are involved in the pathogenesis of benign gastric disease is unknown. Receptor changes in these conditions were therefore sought. An autoradiographic technique was developed to determine quantitatively muscarinic receptors in microtome sections of biopsy specimens obtained during gastroscopy. Muscarinic receptor density was mean (SEM) 18.4 $(1 \cdot 2) \mathrm{fmol} / \mathrm{mg}$ protein in the corpus and $8.9(0.7) \mathrm{fmol} / \mathrm{mg}$ protein in the antrum $(n=53)$. Neither chronic nor active gastritis was associated with receptor changes in the antrum but chronic gastritis was associated with a receptor loss in the corpus. Patients with acute or recent duodenal or antral ulcers $(n=23)$ had significantly higher levels of muscarinic receptors in the corpus than controls $(n=25)(22.2 \quad(1.5) \quad v \quad 16.9 \quad(1.7) \quad \mathrm{fmol} / \mathrm{mg}$ protein respectively $(p<0 \cdot 025)$. These results suggest that muscarinic M3 receptor is overexpressed in duodenal ulcer disease and may play a part in its pathogenesis.

(Gut 1995; 36: 813-818)
\end{abstract}

Keywords: gastric disease, benign, muscarinic receptor subtypes.

Muscarinic receptors and their subtypes ${ }^{1-3}$ have been shown in the gastric mucosa of numerous species and have been localised to parietal, chief, mucous, and endocrine cells. ${ }^{3-11}$ Muscarinic receptors in gastric tissue are coupled to the stimulatory phosphoinositide second messenger system and increase the secretion of hydrogen ions, pepsinogen, and mucous. 5891213 Of the five subtypes of muscarinic receptors known to occur in rats and humans, the M3 receptor has recently been shown to mediate the secretion of gastric acid in rat parietal cells. ${ }^{14}$

Changes in membrane receptors and their coupling systems in human disease have been investigated little up to now, primarily because of a lack of adequate methods. In principle, subtle changes in signal transmission systems may result in considerable alterations in the physiological responses to a given stimulus as a result of the signal amplification associated with second messenger systems. ${ }^{515}$ Moreover, in view of the more than additive or synergistic interaction of the cAMP and the $\mathrm{Ca}^{2+}$ linked second messenger systems in gastric parietal cells, changes in one system may result in considerably amplified or reduced cellular responses, depending on whether the defect results in gain or loss of a function.

At present, there are no studies of possible associations of muscarinic receptor levels in the gastric mucosa of patients with benign human gastric diseases. Since muscarinic receptors mediate the secretion of gastric acid, pepsinogen, and mucous, any changes in their levels might affect a variety of gastric mucosal functions. Biopsy specimens are routinely obtained during gastroscopy, and we have therefore developed a technique that permits microautoradiographic quantification of receptor levels in tissue. ${ }^{1617}$ This technique was used to measure muscarinic receptor levels in the gastric corpus and antrum of 56 patients. The data were analysed in respect of the histological classification ${ }^{18}$ of biopsy specimens and patient characteristics to obtain information on changes in muscarinic receptors in various benign gastric diseases.

\section{Methods}

N-methylscopolamine (NMS) was obtained from Sigma (Taufkirchen, Germany); atropine and gelatine were from Merck (Darmstadt, Germany); and trishydroxyaminomethane (Tris) was from Boehringer, Mannheim. $\left[{ }^{3} \mathrm{H}\right] \mathrm{NMS}$ was purchased from Amersham (UK) $(72 \mathrm{Ci} / \mathrm{mmol}$ specific activity) or from New England Nuclear $(85 \mathrm{Ci} / \mathrm{mmol}$ specific activity). Autoradiography ${ }^{3} \mathrm{H}-\mathrm{Hyperfilm}$ was from Amersham.

Cryotome sections $(10 \mu)$ of frozen tissue were cut at $-23^{\circ} \mathrm{C}$ and applied to glass slides coated with a solution of $0.5 \%$ gelatine and $0.05 \%$ chromium sodium sulphate. The slides were then dried under reduced pressure at $4-8^{\circ} \mathrm{C}$ for one hour.

Radioligand binding experiments were performed by incubating the cryotome sections with 2 nM $\left[{ }^{3} \mathrm{H}\right] \mathrm{NMS}$ with or without unlabelled ligand in $50 \mathrm{mM}$ Tris buffer, $\mathrm{pH}$ $7 \cdot 5$, at $22^{\circ} \mathrm{C}$ for 60 minutes. Incubations were stopped by washing the slides in $250 \mathrm{ml}$ ice cold Tris buffer ( $\mathrm{pH} 7 \cdot 5$ ) for 15 seconds, and then for 30 and 60 seconds. The slides were dried and either wiped with glass fibre filters (GFC, Whatman) for liquid scintillation spectrophotometry or placed next to $x$ ray film for 8-12 weeks in light-proof $x$ ray cassettes without screens at ambient temperature for autoradiography.

To establish the autoradiographic technique, experiments were performed with slices 

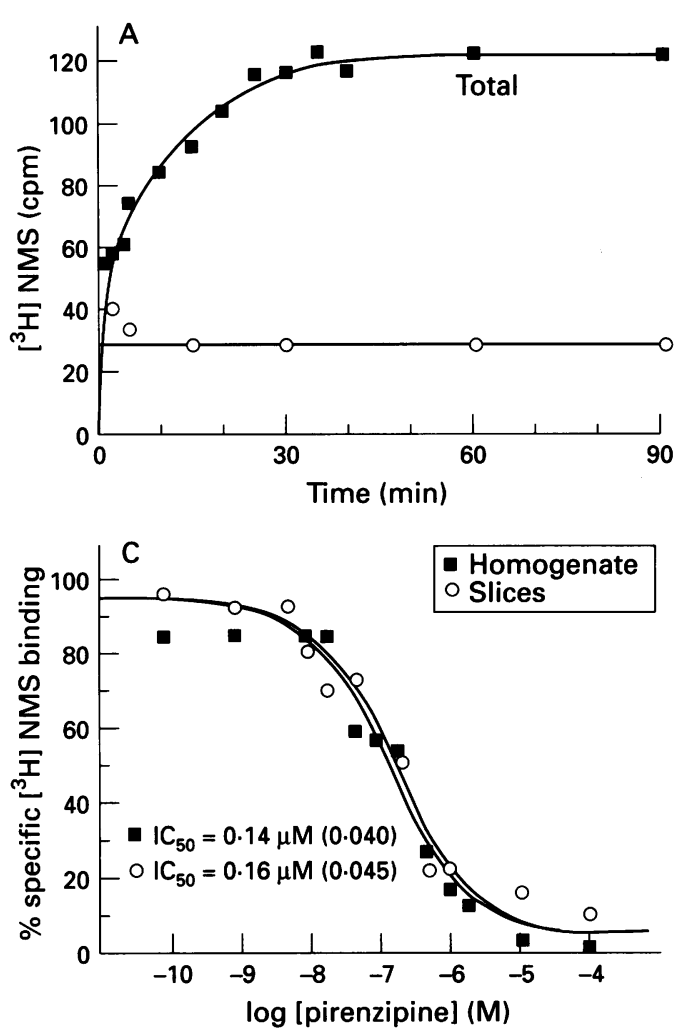

of human gastric mucosa obtained from the proximal borders of antrectomies performed because of recurrent ulcer disease and stored frozen at $-70^{\circ} \mathrm{C}$ until use. Binding equilibrium was reached in 45 minutes and was stable until 90 minutes (Fig 1A). Binding was reversible, as shown by complete dissociation of $\left[{ }^{3} \mathrm{H}\right] \mathrm{NMS}$ with a dissociation half time of 13 minutes at $0^{\circ} \mathrm{C}$. The equilibrium dissociation constant was determined by saturation binding of N-methylscopolamine. It was calculated using the Scatchard technique in the curve fitting program Ligand by Munson and Rodbard. ${ }^{19} 20$

Figure $1 \mathrm{~B}$ shows a direct single estimate of the $K_{D}$ of $\left[{ }^{3} \mathrm{H}\right]$ NMS of $0 \cdot 14 \mathrm{nM}$. This may be compared to the value of $0.39(0.08) \mathrm{nM}$ obtained previously in homogenate assays of 11 individuals. ${ }^{17}$ To establish that NMS had similar binding kinetics in both the slice and normal homogenate assays as performed previously, ${ }^{10} \quad\left[{ }^{3} \mathrm{H}\right] \mathrm{NMS} / \mathrm{NMS}$ inhibition experiments were performed on several slice preparations using $0.25 \mathrm{nM}\left[{ }^{3} \mathrm{H}\right] \mathrm{NMS}$. The calculated $K_{D}$ value of $0.42(0.22) n M(n=3)$ agrees well with the equivalent value previously obtained in homogenates $(0.39(0.08) \mathrm{nM}) .{ }^{17}$

The values for pirenzepine inhibition of $\left[{ }^{3} \mathrm{H}\right]$ NMS binding are very similar using either receptor binding technique. Figure $1 \mathrm{C}$ shows the result of a single experiment in which both a slice assay and a regular homogenate assay were performed in parallel using $0.5 \mathrm{nM}$ $\left[{ }^{3} \mathrm{H}\right] \mathrm{NMS}$. In three separate experiments performed on three separate slice preparations using $0.25 \mathrm{nM}\left[{ }^{3} \mathrm{H}\right] \mathrm{NMS}$, the $\mathrm{K}_{\mathrm{D}}$ value of pirenzepine was 171 (91) $\mathrm{nM}$, which compares well with the value of 148 (32) $n M(n=13)$ determined previously. ${ }^{10}$

For quantification of autoradiographic

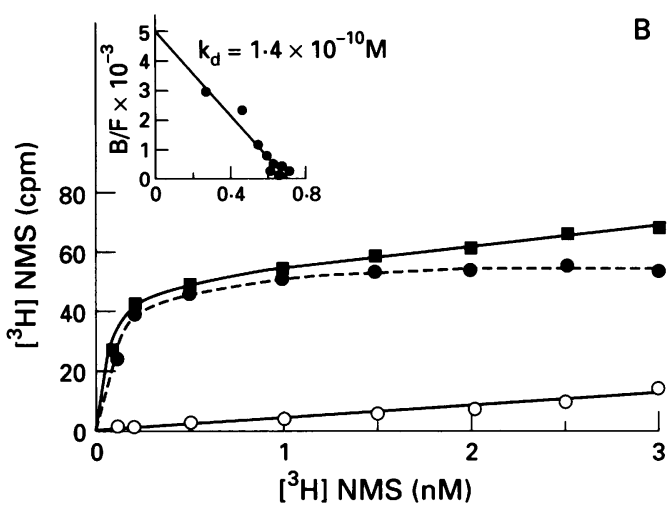

Figure 1: Binding kinetics of $\left[{ }^{3} \mathrm{H}\right] \mathrm{N}$-methylscopolamine $\left.\left({ }^{3} H\right] N M S\right)$ to gastric mucosal tissue slices. Binding was determined by liquid scintillation spectrophotometry (see Methods). The data show representative experiments performed in triplicate/point; each experiment was repeated 3-11 times. (A) Association curve of $2 n M\left[{ }^{3} H\right] N M S$ to slices of human gastric mucosa. Non-specific binding was determined in the presence of $10 \mu M$ atropine.

(B) Saturation curve of $\left[{ }^{3} \mathrm{H}\right] N M S$ to slices of human gastric corpus mucosa. The insert shows a Scatchard plot of the data; units for the $x$ axis are fmol/3 slices. Open and closed circles show non-specific and specific binding, respectively. Closed squares show total binding. Note the very low level of non-specific binding in the presence of 10 $\mu M$ atropine. (C) Displacement of $0.5 n M\left[{ }^{3} H\right] N M S$ by unlabelled pirenzepine in the slice assay compared with the classic homogenate assay. Experiments were performed in parallel using the same tissue.

results, standardised scales with eight known amounts of radioactivity ( ${ }^{3} \mathrm{H}$-Microscales, Amersham) were coexposed with each film and used to construct reference curves. The blackening of the film was quantified by computerised videodensitometry using a Panasonic WV-LD $130 \mathrm{~L}$ video camera and a PCD-2 computer from Siemens (Erlangen, Germany). The grey levels in the samples were calculated in an area held constant after subtraction of film background. Non-specific binding was determined in parallel sections which contained $10 \mu \mathrm{M}$ unlabelled atropine during the incubation with $\left[{ }^{3} \mathrm{H}\right] \mathrm{NMS}$, and was subtracted from the total radioactivity.

To obtain direct comparisons for the film autoradiographic technique, the radioactivity bound to slices from gastric mucosa was measured by liquid scintillation counting and by autoradiography in parallel. The protein content of a slice from a gastric biopsy was 2-4 $\mu \mathrm{g} /$ section $(n=8)$, as determined with the Bradford assay. ${ }^{21}$ Protein was dissolved in 0.5 $\mathrm{N} \mathrm{NaOH}$ and neutralised with $0.5 \mathrm{~N} \mathrm{HCl}$ before addition of the Coomassie brilliant blue reagent. The embedding material, Tissue Tek (Miles, Elkheart, Indiana, USA) was washed away during the washing procedure and did not interfere with the Bradford assay. The radioactivity specifically bound, determined in 4 sections/point was between $1-30 \mathrm{fmol} / \mathrm{mg}$ protein for the different human biopsy specimens tested. Using the same technique for porcine gastric mucosa, the value determined by the slice binding assay was $30.7 \mathrm{fmol} / \mathrm{mg}$ protein which corresponds to values obtained in homogenate binding assays. ${ }^{69}$ These values were employed to calibrate the microscale standards to gastric mucosa. Reproducibility was tested by cutting and labelling slices from 


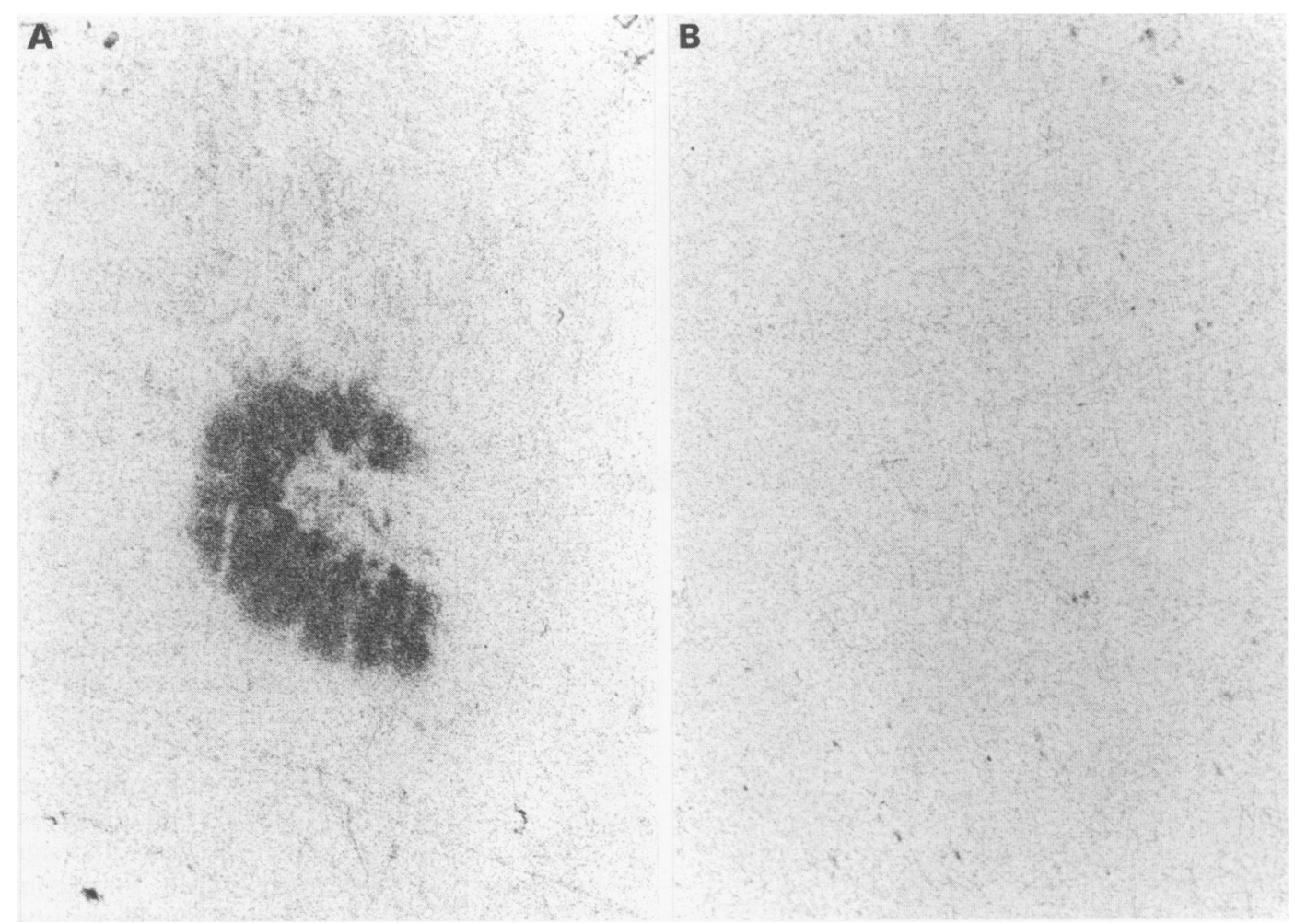

Figure 2: Film autoradiograph of $\left[{ }^{3} \mathrm{H}\right] \mathrm{N}$-methylscopolamine ([ $\left.{ }^{3} \mathrm{H}\right] \mathrm{NMS}$ ) labelling of muscarinic receptors in a biopsy specimen for the gastric corpus $\left((A)\right.$ total binding, $(B)$ non-specific binding). Non-specific binding of $\left[{ }^{3} H\right] N M S$ determined in the presence of $10 \mu M$ atropine is extremely low and not detected by film autoradiography.

adjacent pieces of porcine mucosa in three separate experiments. The intra- and interassay coefficients of variation were $5 \%$ and $11 \%$ respectively.

\section{PATIENTS}

The project was approved by the ethical commission of the University of Bochum. Patients involved were informed about the study and gave their consent. Each patient was interviewed with regard to his or her medical history, in particular gastrointestinal disorders and operations, smoking habits, and medication. Fifty six consecutive patients who agreed to participate had a biopsy specimen taken from the gastric corpus at the major curvature approximately opposite to the angulus and a second from the antrum, approximately $2 \mathrm{~cm}$ proximal to the pylorus. The mean age of the 12 male and 13 female patients without ulcer disease was 54 (3) years and that of the 10 male and 13 female ulcer patients was 63 (3) years. Control gastroscopies were performed to exclude gastric disease in patients with gall stones, right upper quadrant pain, positive stool blood test, or irritable bowel syndrome.

The biopsy material was embedded in a drop of Tissue Tek (Miles, Elkheart, Indiana, USA) immediately frozen on dry ice, and stored at $-70^{\circ} \mathrm{C}$. The frozen tissue was cut into $10 \mu$ slices with a cryotome as described above. Incubations were performed with 4 slices/slide as described above.

Every fifth section of a biopsy specimen adjacent to those used in binding experiments was stained with haematoxylin and eosin and evaluated histologically according to the Sydney system for the classification of gastritis ${ }^{18}$ without knowledge of the results of autoradiography.

\section{STATISTICS}

Values are reported as mean (SEM). Statistical comparisons between groups employed analysis of variance and Duncan's multiple range test when appropriate.

\section{Results}

Biopsy specimens were obtained from 56 patients. These included 25 patients with no history of gastric disease, 18 with a history of duodenal or antral ulcers but no ulcers at the time of investigation, and 13 with acute antral or duodenal ulcers. Among the ulcer patients, four had been treated with a Bilroth II operation and two with a proximal selective vagotomy. One patient with gastrointestinal lymphoma and another with gastric cancer were excluded from the analysis.

Muscarinic receptors were determined by employing binding of the non-selective hydrophilic muscarinic antagonist $\left[{ }^{3} \mathrm{H}\right] \mathrm{NMS}$ to cryotome slices and determination of receptor levels by film autoradiography as described under Methods. [ $\left.{ }^{3} \mathrm{H}\right] \mathrm{NMS}$ permitted excellent labelling of muscarinic receptors with negligible levels of non-specific binding at saturating concentrations of the ligand (Figs 1 and 2).

DISTRIBUTION OF MUSCARINIC RECEPTORS Muscarinic receptor levels in all patients investigated were significantly higher in the 

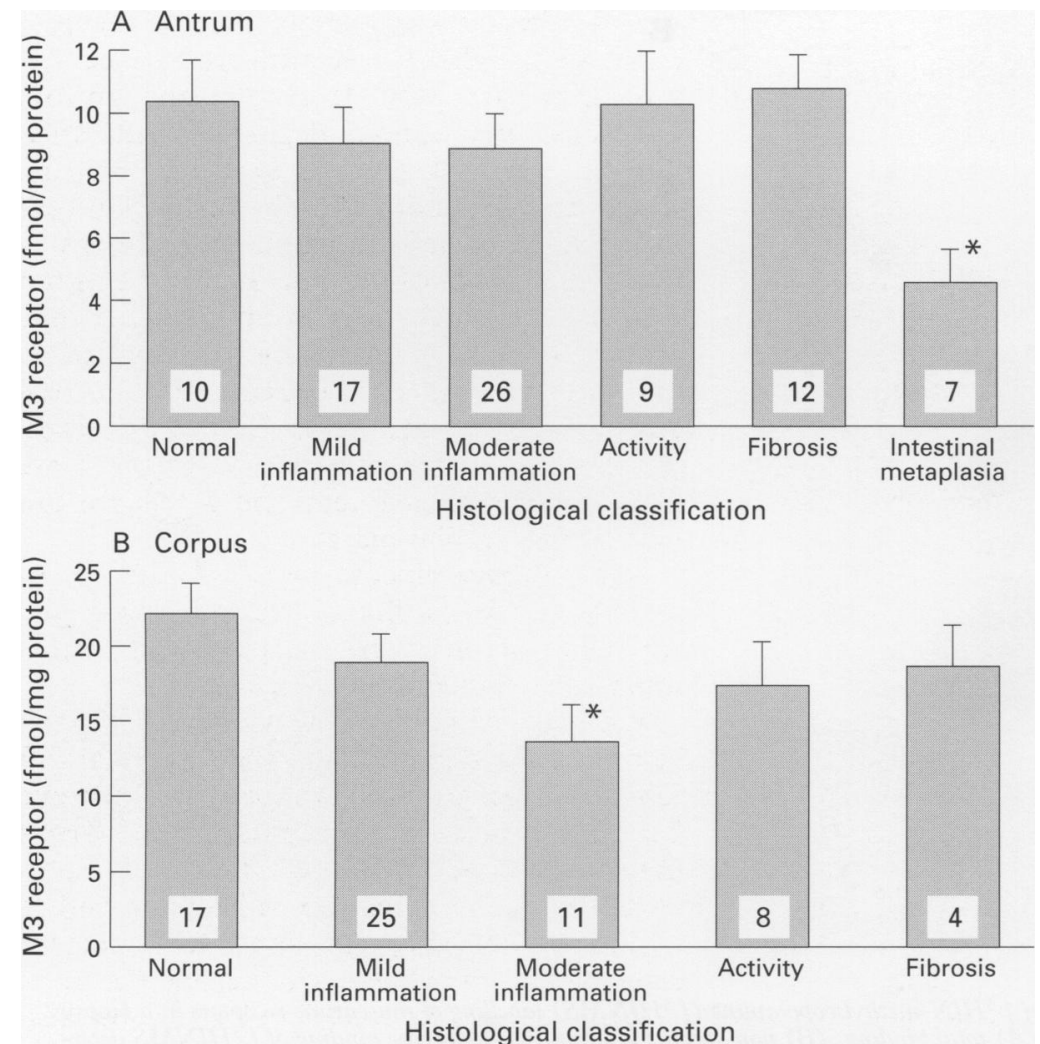

Figure 3: Muscarinic receptor levels and histological classification (Sydney classification ${ }^{11}$ ) of gastric biopsy specimens obtained from the antrum $(A)$ or corpus $(B)$. The biopsies were classified according to the degree of inflammation (none, mild, moderate, severe). Activity, fibrosis or intestinal metaplasia, or atrophy were additionally noted if present and thus represent subgroups of the patients classified with regard to inflammation. ${ }^{\star} p<0.05$ compared to no inflammation. receptors in the antrum were not different between the groups with values of $8.6(1.4)$ $\mathrm{fmol} / \mathrm{mg}$ protein in 23 ulcer patients and $8 \cdot 3$ $(1 \cdot 0) \mathrm{fmol} / \mathrm{mg}$ protein in 23 non-ulcer patients. The mucosa from the gastric corpus of ulcer patients had significantly higher receptor levels than that of non-ulcer patients $(22.2(1.5)$, $\mathrm{n}=23 v 16.9(1.7), \mathrm{n}=25 ; \mathrm{p}<0.025)$.

Because muscarinic receptor levels differed according to the histological appearance of the mucosa, it was of interest to compare ulcer and non-ulcer patients in terms of histological grading. In antral tissue, patients with a history of ulcers and no or mild inflammation had somewhat higher levels of receptors than those without a history of gastric ulcers $(p=0 \cdot 07$, Fig 4A), but the difference did not reach statistical significance. In contrast, antral tissue from ulcer patients with moderate inflammation had significantly lower receptor levels than tissue from ulcer patients with no or mild gastritis (Fig 4A), while such a difference was not observed in non-ulcer subjects.

The corpus mucosa of patients with a history of ulcers had significantly higher receptor levels than that from patients without ulcer disease for the groups with no or mild inflammation ( $<<0.025$; Fig $4 B$ ). Moderate inflammation was associated with comparably reduced receptor levels in both groups (Fig 4B).

\section{ACUTE ULCER DISEASE AND MUSCARINIC RECEPTORS}

Patients with acute prepyloric or duodenal ulcers $(n=12)$ had somewhat higher levels of muscarinic receptors in the corpus than controls (22 (2), $\mathrm{n}=12 v 16.9(1.7) \mathrm{fmol} / \mathrm{mg}$ protein, $n=25$ ). Because moderate inflammation was associated with a loss of muscarinic receptors, patients in this group were analysed separately. In the group with no or mild inflammation $(n=9)$, patients with acute ulcers had significantly higher levels of muscarinic receptors in the corpus than controls $(24.0$ $(1 \cdot 8), \mathrm{n}=9$ v $17 \cdot 2(1 \cdot 8) \mathrm{fmol} / \mathrm{mg}$ protein, $\mathrm{n}=22, \mathrm{p}<0.05)$. Patients with recent ulcers and no or mild inflammation had similar receptor numbers $(23.6(2 \cdot 3) \mathrm{fmol} / \mathrm{mg}$ protein, $\mathrm{n}=9$ ) to patients with acute ulcers. There was no difference between the groups with moderate inflammation.

In the antral mucosa, only five patients with acute ulcers had mild gastritis, and muscarinic receptor levels in these patients were not significantly different from those determined in controls $(14 \cdot 1(2 \cdot 6), \mathrm{n}=5$ v $8.3(1 \cdot 0) \mathrm{fmol} / \mathrm{mg}$ protein, $n=16$ ). However, in the presence of moderate gastritis $(n=7)$, acute ulcer patients had noticeably low receptor levels of $4 \cdot 2(1 \cdot 6)$ $\mathrm{fmol} / \mathrm{mg}$ protein compared with controls with moderate gastritis $(9.6(1.9) \mathrm{fmol} / \mathrm{mg}$ protein, $\mathrm{n}=7$ )

Twenty three patients with present or recent prepyloric or duodenal ulcers were analysed. Patients who had had gastric surgery (four Bilroth II procedure and two a proximal selective vagotomy), were excluded. Receptor levels were compared to those in patients without a history of ulcer disease $(n=25)$. Muscarinic

\section{AGE, SEX, AND MUSCARINIC RECEPTORS}

There were no age related differences in muscarinic receptors in subjects under 75 years of age without a history of ulcer. A decrease in 

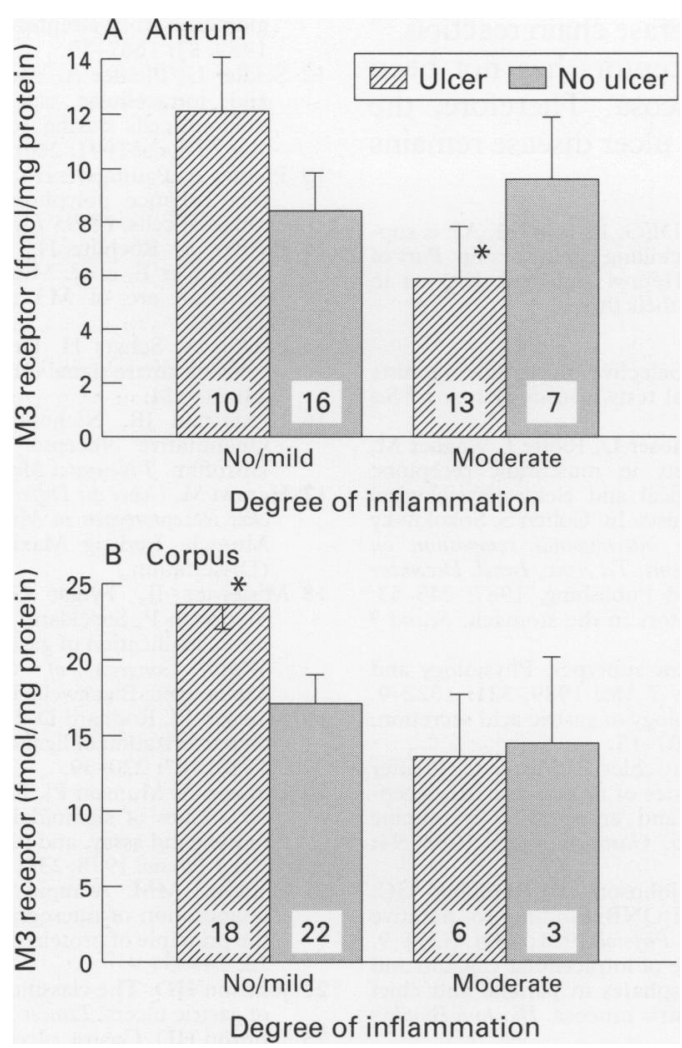

Figure 4: Muscarinic receptor levels in the gastric antrum $(A)$ or corpus (B) in ulcer $\mathrm{v}$ non-ulcer patients. $(A){ }^{\star} p<0.05$ compared with ulcer patients with no/mild inflammation. (B) ${ }^{\star} p<0.025$ compared with non-ulcer subjects with no/mild inflammation.

muscarinic receptors was seen in three subjects older than 75 years in histologically normal or mildly inflamed corpus and antral mucosa, but this group was to small for analysis. Receptor levels did not differ depending on the sex or smoking habits of the subjects. The intake of $\mathrm{H}_{2}$ antagonists $(\mathrm{n}=11)$ or of non-steroidal anti-inflammatory drugs $(n=7)$ was not associated with changes in muscarinic receptors compared with subjects who were not taking these drugs.

\section{Discussion}

To our knowledge this is the first study which has applied receptor autoradiography to the study of mucosal receptors in gastroscopically obtained biopsy material from humans. The advantage of the technique is obvious as it enables investigation of receptor levels in normal subjects and in patients with various gastric diseases who are not treated surgically. Furthermore, it is possible to monitor precisely the histological appearance of the specimen investigated, in contrast to membrane binding assays.

Muscarinic receptors had an unequal anatomical distribution with twofold higher levels in the mucosa of the corpus than in the antrum. This may relate to a higher density of receptors in parietal and chief cells of the corpus than in mucous cells in the antrum.

Receptor levels were analysed with regard to histological classification of the sections irrespective of a previous history of gastric disease to determine whether various types of gastritis were associated with distinct levels of receptor expression. There were no differences in muscarinic receptor density in the antrum associated with various degrees of inflammation as signs of chronic gastritis. Activity, which describes infiltration by neutrophil cells in addition to inflammation and fibrosis, a non-specific sign of previous injury, ${ }^{18}$ was not associated with changes in antral muscarinic receptors. A $50 \%$ reduction in muscarinic receptors was evident in patients with mucosal atrophy or intestinal metaplasia. This might be expected, since muscarinic receptors are located on epithelial cells and levels are not measurable on fibroblasts.

In the corpus mucosa, signs of mild inflammation, activity, or fibrosis were not associated with a loss of muscarinic receptors while such a loss was seen in chronic gastritis.

A comparison of patients with and without a history of duodenal ulcers showed several differences between these groups. Ulcer patients had more muscarinic receptors in the corpus than non-ulcer patients. This was also observed in the subgroup of patients with a current ulcer, who, moreover, had receptor levels similar to patients with healed ulcers.

Ulcer disease is considered a chronic disorder with a recurrent character. Most investigators agree that antral and duodenal ulcers are associated with an increased or prolonged output of gastric acid, either basally or in response to a meal. ${ }^{2223}$ Recent data also suggest that the increased production of acid persists after healing of ulcers. ${ }^{24}$ Our data suggest that muscarinic receptor levels may be high in the corpus of patients with present or healed ulcers. Most muscarinic receptors in the corpus are located on the acid producing parietal cells and on pepsinogen producing chief cells. Overexpression of muscarinic receptors could therefore provide a good explanation for increased output of acid and of pepsinogen, and add a possible pathophysiological cause to the development of peptic ulcer disease.

In the antral mucosa, ulcer patients had levels of muscarinic receptors similar to those of non-ulcer subjects as a whole. The few acute ulcer patients with mild gastritis tended to have higher receptor levels than non-ulcer subjects, however, supporting the idea of a general increase throughout the stomach in muscarinic receptors occurring in this subgroup of duodenal ulcer patients. A marked loss of muscarinic receptors was seen in the antrum of those ulcer patients with more pronounced gastritis. The reason for this loss is unclear since there was no histological difference between these patients and non-ulcer subjects.

Recent investigations suggested that the M3 subtype of muscarinic receptors mediates acid secretion in isolated rat parietal cell preparations. ${ }^{14}$ The presence of muscarinic M3 receptor types in human gastric mucosa was previously suggested by radioligand binding studies ${ }^{10}$ and was demonstrated by amplification of a fragment of the unique third cytoplasmic loop of the muscarinic M3 receptor from cDNA isolated from human gastric biopsy 
material using the polymerase chain reaction. ${ }^{25}$ The presence of $M 1$ receptors has not been excluded in human mucosa. Therefore, the subtype overexpressed in ulcer disease remains to be determined.

This study was supported by the DFG, Pf 164/7-2. AP is supported by a Hermann and Lilly-Schilling professorship. Part of ported by a Hermann and Lilly-Schilling professorship. Part of this study was performed by $M$ Herawi and
fulfilment of the requirements for their theses.

1 Mutschler E, Lambrecht G. Selective muscarinic agonists and antagonists in functional tests. Trends Pharmacol Sci and antagonists in

2 Lambrecht G, Mutschler E, Moser U, Riotte J, Wagner M, Wess $\mathrm{J}$, et al. Heterogeneity in muscarinic receptors evidence from pharmacological and elektrophysiological studies with selective antagonists. In: Cohen S, Sokolovsky $\mathrm{M}$, eds. Proceedings of the international symposium on muscarinic cholinergic mechanisms, Tel Aviv, Israel, December
1-4, 1986. Tel Aviv: Freund Publishing, 1987: 245-53.

3 Hammer R. Muscarinic receptors in the stomach. Scand $\mathcal{J}$ Gastroenterol 1985; 15: 5-11.

4 Goyal RK. Muscarinic receptor subtypes. Physiology and clinical implication. Wolfe $M$, Soll AH. The physic N Engl f Med 1988; 319: 1707-15.

6 Herawi M, Lambrecht G, Mutschler E, Moser U, Pfeiffer A. Different binding properties of muscarinic M2-receptor suntypes for agonists and antagonists in porcine smooth muscle and mucosa. Gastroenterology 1988; 94 630-7.

7 Ecknauer R, Thompson WJ, Johnson LR, Rosenfeld GC. Isolated parietal cells: [ $3 \mathrm{H}] \mathrm{QNB}$ binding to putative cholinergic receptors. Am f Physiol 1981; 239: G204-9.

8 Chew CS, Brown MR. Release of intracellular calcium and elevation of inositol trisphosphates in parietal and chief cells isolated from rabbit gastric mucosa. Biochim Biophys Acta 1986; 888: 116-25.

9 Pfeiffer A, Rochlitz H, Herz A, Paumgartner G. Stimulation of acid secretion and phosphoinositol production by parietal cell muscarinic M2 receptors. Am $¥$ Physiol 1988; 254: G622-9.

10 Pfeiffer A, Hanack C, Kopp R, Tacke R, Moser U, Mutschler $\mathrm{E}$, et al. Human gastric mucosa expresses the M3-subtype of muscarinic receptors. Dig Dis Sci 1990; 35: 1468-72.

11 Craven PA, DeRubertis FR. Protein kinase C is activated in glomeruli from streptozotocin diabetic rats. $\mathcal{f}$ Clin Invest 1989; 83: 1667-75.

12 Seidler U, Pfeiffer A. Formation of polyphosphoinositides and intracellular calcium-changes in rabbit gastric mucous cells during secretagogue-induced stimulation Am f Physiol 1991; 260: G133-41.

13 Pfeiffer A, Paumgartner G, Herz A. Muscarinic M2 receptors enhance polyphospoinositol release in rat gastric mucosal cells. FEBS Lett 1986; 204: 352-6.

14 Pfeiffer A, Rochlitz H, Noelke B, Tacke R, Moser U, Mutschler E, et al. Muscarinic receptors mediating acid secretion are of M3 type. Gastroenterology 1990; 98: 218-22.

15 Pfeiffer A, Schatz H. Pathophysiological aspects of nontyrosine kinase signal transduction. Horm Metab Res 1992; 24: 219-24.

16 Unnerstahl JR, Niehoff DL, Kuhar MJ, Palacios JM Quantitative receptor autoradiography using $3 \mathrm{H}-$ Ultrofilm. I Neurosci Methods 1982; 6: 59-73.

17 Herawi M. Ueber die Differenzierung verschiedener muskarinischer Rezeptortypen in Muskularis und Mukosa des Magens. Munich: Ludwig Maximilians Universitaet, 1987: 95. (Dissertation.)

18 Misiewicz J, Tytgat GNJ, Goodwin CS, Price AB, Sipponen P, Strickland RG, et al. The Sydney system: a new classification of gastritis. In: Working party reports, 9 th World Congress of Gastroenterology, Sydney 1990. Melbourne: Blackwell, 1990: 1-10.

19 Munson PJ, Rodbard D. LIGAND: a versatile approach for characterization of ligand binding systems. Analyt Biochem 1980; 107: 220-39.

20 DeLean A, Munson PJ, Rodbard D. Simultaneous analysis of families of sigmoidal curves: application to bioassay, radioligand assay, and physiological dose response curves. Am f Physiol 1978,

21 Bradford MM. A rapid and sensitive technique for the quantitation of microgram quantities of protein utilizing the principle of protein dye binding. Analyt Biochem 1976; 72: 248-54.

22 Johnson HD. The classification and principles of treatment of gastric ulcers. Lancet 1957; ii: 515-7.

23 Johnson HD. Gastric ulcers: Classification. Ann Surg 1965; 162: 996-1004.

24 Wagner S, Gladziwa U, Gebel M, Schüler A, Freise J, Schmidt FW. Circadian pattern of intragastric acidity in duodenal ulcer patients: a study of variations in relation to ulcer activity. Gut 1991; 32: 1104-9.

25 Rochlitz H, Kopp R, Pfeiffer A. Charakterisierung der Muskarinrezeptor-Subtypen in Magen- und Colonschleimhaut mit der Polymerase-Kerrenreaktion. Z Gastroenterol 1992; 30: 673. 